\title{
THE CHILD AND THE CHILD-LIKE IN DANIIL CHARMS
}

\author{
LARISSA TUMANOV \\ VLADIMIR TUMANOV
}

Прощание с друзьями

В широких шляпах, длинных пиджаках, С тетрадями своих стихотворений, Давным-давно рассыпались вы в прах, Как ветки облетевшие сирени.

Вы в той стране, где нет готовых форм, Где все разъято, смешано, разбито, Где вместо неба - лици могильный холм И неподвижна лунная орбита.

Там на ином, невнятном языке Поет синклит беззвучных насекомых, Там с маленьким фонариком в руке Жук-человек приветствует знакомых.

Спокойно ль вам, товарищи мои? Легко ли вам? и все ли вы забыли? Теперь вам братья - корни, муравьи, Травинки, вздохи, столбики из пыли.

0304-3479/93/\$06.00 @ 1993 - Elsevier Science Publishers B.V. All rights reserved. 
Теперь вам сестры - цветики гвоздик,

Соски сирени, щепочки, цыплята...

И уж не в силах вспомнить ваш язык

Там наверху оставленного брата.

(N.Zabolockij)

In memoriam:

D. Charms, A. Vvedenskij

\section{Introduction}

In his lifetime Daniil Charms only succeeded in publishing two of his poems for adults. ${ }^{1}$ Publicly he was a children's author: a job in the Soviet Union which traditionally attracted many writers' whose literature for adults was either rejected by the official literary system or had to be hidden altogether if its creators wanted to avoid trouble. As L. Loseff points out:

Ever since the 1920s [...] the most prominent writers had extended their energies [to Russian children's literature]: Yesenin, Zoshchenko, Mandelstam, Mayakovsky, Pasternak, Platonov, Prishvin; members of the avant-garde group Oberiu - Vvedensky, Zabolotsky, Kharms - and such like-minded writers as Vladimirov, Oleynikov, and Shvarts.

(Loseff 1984: 193)

In fact up to the present day it is still Charms the children's author who is best known and loved, although finally under new historical and political conditions the writer for adults has also been allowed to make his debut. However, whatever he wrote, Charms' work was always dominated by an absurdist world view, a view that usually denied all dogma or ideology. His only aim seems to have been to present a world upside down and play around with literary and other conventions, i.e. more than anything else he wanted to be different, acting as a sort of literary 'punk'.

Although Charms and his associates were preceded by European absurdist authors, such as A. Jarry (1873-1907), it is very difficult to establish any relationship of influence between examples of Western European absurdism and Daniil Charms. Nonetheless, Charms' work, as well as that of Jarry, Ionesco and Beckett, all share the "grotesquely comic as well as irrational" (Abrams 1981: 1) quality of the absurdist movement in its larger modernist context. In fact Ionesco's definition of the absurd can just as easily apply to Charms: 
Absurd is that which is devoid of purpose [...] Cut off from his religious, metaphysical, and transcendental roots, man is lost; all his actions become senseless, absurd, useless.

(Esslin 1980: 23)

Charms' world is indeed purposeless and irrational: one often has the impression that characters and events are part of a mathematical game where elements are constantly arranged and rearranged in different curious and bizarre combinations with little regard for the concerns of the real world. These qualities of Charms' absurdism appear similar to the absurd worlds of Western European authors because of the very specific nature of the literature of the absurd, which is essentially purposely antidogmatic and seeks to be the reverse of the familiar and the 'normal'? However, as to the question of influence, it is probably most fruitful to turn to Russian literature and look for Charms' roots in the work of such authors as Gogol' and Dostoevskij. As a matter of fact, François Jost points out that curiously enough it may have been Russian literature in the first place that influenced the Western European absurdists and existentialists:

[...] a contemporary critic could reasonably try to defend the hypothesis that the literature of the absurd is essentially Slavic in origin with a dramatist like the Romanian Ionesco as an intermediary.

(Jost 1974: 77)

Polysystem theory analyses the existence of complex interactions and interrelations between literatures within the literary polysystem, and, as Itamar Even-Zohar points out, "[...] literature for children is not considered a phenomenon sui generis, but is related to literature for adults" (1979: 292). Because Charms' works consist of literature that is part of the traditionally-viewed center - literature for adults - as well as literature located at the periphery - children's literature - his oeuvre can be seen as a microsystem in itself, characterized by a definite interplay between the two literatures. Now that access to most of Charms' works is permitted and possible, we can see what features his works 'written for children' and those 'written for adults' have in common. As G. Gibian puts it:

[Charms'] poems and stories for children veer toward adult literature; stories and plays for adults resemble literature for children and the writings of the insane.

(Gibian 1987: 42) 
However, at the same time we would like to address the differences between Charms' children's works and his literature for adults: differences determined by socio-political factors as well as genre-related phenomena.

\section{Games: Language, Genre and Form}

Play with language in Charms, which often results in baby sounds or nonsense syllables coming out of characters' mouths, is very common, and - in spite of the Obèriu manifesto ${ }^{3}$ - echoes similar Futurist experimentation, e.g. V. Chlebnikov's transrational poems. In a number of works - for adults and for children - Charms engages in purely phonemic games, where phonic elements take center-stage and throw their semantic counterparts out of the way. For example, in 'Veselyj staričok' we see a whole children's poem which rings with crazy and perhaps even senile laughter:

Жил на свете старичок
Маленького роста,
И смеялся старичок
Чрезвычайно просто:
"Ха-ха-ха
Да хе-хе-хе
Хи-хи-хи
Да бух-бух!
Бу-бу-бу
Да бе-бе-бе
Динь-динь-динь
Да трюх-трюх!"

(1988:252)

Whereas the old man's laughter is given in a conventional way at first: "Cha-cha-cha, da che-che-che, chi-chi-chi", this traditional Russian 'laughter notation' is followed by sounds which are normally not used in Russian to indicate laughter or, for that matter, anything else. This conventional or rational beginning and eccentric or absurd continuation reflect a general sequential pattern in Charms' work: in a typical Kharmsian series, set or list of elements the usual normally comes first and the deviation acts as a kind of disruption of the reader's expectations. Therefore, a familiar background is established by the conventional Kharmsian beginning, and an unfamiliar foreground shocks the reader out of his automatized stupor. Compare this penchant toward the progressive semantic (sequential) absurdization of lists with a similar phenomenon in 
the work of Eugène Ionesco: "Le yaourt est excellent pour l'estomac, les reins, l'appendicite et l'apothéose" (1954: 11).

The displacement of the semantic by the phonic, similar to the old man's laughter in the above-mentioned example, takes place in a children's story called 'Chvastun Kolpakov'. Here the braggart Kolpakov tries to prove his bravery by diving into the water; unfortunately he begins to drown and utters the delightful and meaningless "njav... njav... njav..." (1990: 153) instead of the conventional "bul'... bul'... bul'...", which is normally used in Russian to approximate the sound made by a drowning person. And as an example of this game from Charms' corpus for adults we can cite the poem "Mest" where the character of Faust exclaims to the 'writers':

\author{
Pya peo \\ кио лау \\ кони фиу \\ пеу боу. Мыс. Мыс. Мыс. \\ (1988: 101)
}

As opposed to the phoneme strings in the previous examples where human beings, and adult human beings at that, speak utter nonsense, seemingly 'motivated' use of nonsense syllables can be found in a children's story about a dog who shows his painting to all sorts of animals, including a monkey. The simian speaks as a simian 'should':

Бал бал бал бал

Бол бол бол бол

Лок вок мок роп

Лук лак лик лек!

(1990:149)

This sort of motivated group of nonsensical phonemes can also be found in a poem written by Professor Trubočkin, one of Charms' well-known children's characters who appeared in a series of adventures in the 1933 editions of the children's magazine Čiž:

Жик жик жик.

Фок фок фок.

Рик рик рик.

Шук шук шук.

(1990: 124)

The professor explains that the poem is written in the language called 'Fistoltian'. This agglomeration of morphemes or phonemes, which in 
many cases are not even Russian, serves to deautomatize our sense of the Russian language, to push our normal phonic reflexes out of their familiar pathways. ${ }^{4}$

Play with genre conventions is another ludic feature that characterizes both Charms' children's literature and his works for adults. One such genre game involves a traditional children's genre - the fairy tale with which every one young and old is so familiar, that its violation is particularly noticeable:

The fairy tale seems to me one of the most important and influential of all literary genres: after all, most children, and therefore also most writers, receive their first and decisive impulses to the future workings of their imaginations from the tales they are told as children.

(Esslin 1982: 22)

Taking familiarity with this genre as a given, Charms plays with the most basic fairy-tale conventions in several of his stories. In the children's story aptly called 'Skazka', there are two children: Vanja, who wants to write a typical fairy tale, and Lenočka, who says that each fairy tale proposed by Vanja has been written; she then proceeds to tell her extremely unique versions of these stories. For example, Vanja suggests writing about a highwayman, and Lenočka tells him the absurd tale of the highwayman who tried to escape on a horse but had a lot of trouble:

Разбойник вскочил на лошадь, да с размаху перевалился
на другую сторону и упал на землю. Разбойник выру-
гался и опять вскочил на лошадь но снова не расчитал
прыжка, перевалился на другуг сторону и упал на зем-
лп.. Тогда разбойник сорвал с головы шапку, растоптал
ее ногами и опять прыгнул на лошадь, и опять пере-
махнул через нее, шлепнулся на землю и сломал себе но-
гу. А лошадь отошла в сторону. Разбойник, прихрамы-
вая, подбежал к лошади и ударил ее кулаком по лбу.
Лошадь убежала. В это время прискакали стражники,
схватили разбойника и отвели его в тюрьму. (1988:276)

In this anti-climactic piece nothing much happens: it is a story that, like its protagonist, seems unable to get moving. The fairy tale, which is normally full of action and adventure - especially when a "razbojnik" is involved - becomes a failure caused by the simple laws of gravity pushed to the point of absurdity. Such purely 'physical' considerations usually 
have no bearing on fantasy in the more conventional manifestations of the fairy tale genre.

In Charms' literature for adults two other 'deformed' fairy tales can be cited; one is called playfully 'Skasska' - a phonetic transliteration of the word 'skazka' - and the other bears the title 'Novyj talantlivyj pisatel". In the former, the conventional fairy tale beginning "Žil-byl" - the equivalent of "Once upon a time" - seems to promise the kind of story that most readers are familiar with. However, it introduces not a character from a work of fantasy, but an ordinary person with the very ordinary name "Semenov", which is clearly a foreign element in a world introduced by "žil-byl" along with its panoply of connotations. As he is walking along, this absent-minded adult character loses everything he has and then eventually "loses himself", so that nothing else can happen in the story: it has to end. Just as in the story about the highwayman, the fairy tale adventures that we might expect after "žil-byl" are over before they even begin:
Жил-был один человек, звали его Семенов. Пошел од- нажды Семенов гулять и потерял носовой платок. Семе- нов начал искать носовой платок и потерял шапку. На- чал шапку искать и потерял куртку. Начал куртку искать и потерял сапоги.
- Ну, сказал Семенов, этак все растеряешь. Пойду луч- ше домой.
Пошел Семенов домой и заблудился.
- Нет, сказал Семенов, лучше я сяду и посижу.
Сел Семенов на камушек и заснул.
(Jaccard 1985: 289)

Here, just as in the story about the highwayman, a series of mishaps is multiplied to the point of absurdity, i.e., one or two of these misadventures could be accepted by the reader as something believable, but they are so numerous that their sheer number takes center stage and pushes the story line into the background. Our attention is attracted not by what happens but by how many times it happens.

The story "Novyj talantlivyj pisatel" starts off just like the previous unrealized 'fairy tale', i.e., with a conventional beginning that seems to promise the ordinary material of fairy tales: there is a prince in a castle. However, it quickly takes a twist, as the subject and language of the work take on a very adult tone:

В одном старинном замке жил принц, страшный пьяница. А жена этого принца, наоборот, не пила даже чаю, только воду и молоко пила. А муж ее пил водку и вино, а 
молока не пил. Да и жена его, собственно говоря, тоже водку пила, но скрывала это. А муж был бесстыдник и не скрывал. "Не пью молока, а водку пью!" - говорил он всегда. А жена тихонько, из-под фартука, вынимала баночку и хлоп, значит, выпивала...

(Glocer 1987: 266)

Once again we have a story that does not seem able to take off: a background description continues for longer than expected, abounds with ridiculous and clearly associative narrative and ends up replacing the plot entirely. Just as in the previous examples, the action-packed fairy tale genre is subverted. After the traditional 'prince in an old castle' beginning, the child's world with its formulaic fairy tale language is quickly forgotten as we read in very colloquial adult language about sordid adult activities.

The fable is another well-known literary genre with which Charms plays in both his children's literature and literature for adults. Krylov's famous 'Zajac i cerepacha' is the model for a children's story, which is made absurd from the very opening sentence where one of the characters, "žirafa", is given in the wrong gender:

Однажды лев, слон, жирафа, олень, страус, лось, дикая лошадь и собака поспорили, кто из них быстрее всех бегает.

Спорили, спорили и чуть было не подрались.

Услыхал Гриша Апельсинов, что звери спорят, и говорит им:

- Эх вы, глупые звери! Зря вы спорите! Вы лучше устройте состязание. Кто первый вокруг озера обежит, то, значит, и бегает быстрее всех.

(Krylov 1988: 272)

Not to mention the anachronistic and at the same time ridiculous name of the human who suddenly steps into a genre where he would normally not be found, the absurd sequence and results of the race challenge the traditional genre expectations of the reader: the lion, just like the hare in the original fable, drops off to sleep under the palm trees; the ostrich, wanting to get ahead, suggests to the moose and the giraffe that they all three quickly drink the water from the lake and then run across the dry lake bed; then the cunning ostrich leaves the other two to drink and runs off alone - but in the wrong direction, toward the start; the elephant sees the moose and the giraffe drinking the lake, goes into a fit of laughter and cannot stop; the dog, who has fleas, stops running and is unable to 
stop scratching; finally the horse and the deer win the race, thereby undermining the traditional 'single victor' ending.

Equally untraditional is a yet unpublished 'fable' entitled 'Četveronogaja vorona', which is modelled on the well-known Krylov fable 'Vorona i lisica'. It is difficult to determine whether this text was meant for children or for adults:

Жила была четвероногая ворона. Собственно говоря у нее было пять ног, но об этом говорить не стоит.

Вот однажды купила себе четвероногая ворона кофе и думает: "Ну вот, купила я себе кофе, а что с ним делать?"

А тут, как на беду, пробегала мимо одноногая лиса. Увидала она ворону и кричит ей: "Эй, кричит, ты, ворона!"

А ворона лисе кричит:

"Сама ты ворона!"

А лиса вороне кричит:

"А ты, ворона, свинья!"

Туг ворона от обиды рассыпала кофе. А лиса прочь побежала. А ворона слезла на землю и пошла на своих четырех, или точнее, на пяти ногах в свой паршивый дом.

(Druskin Fund Archives No. 367)

The absurd elements have a structural/ludic logic of their own in this 'anti-fable'. Although the crow is four-legged, the fox is one-legged, acting as the absurd symmetrical complement to this avian 'multipodicity'. Furthermore, the crow takes offense when the fox calls it a crow, and this absurd 'insult' stands in opposition to the praise offered by the fox in Krylov's original fable. This strange insult, just like the praise in the original, acts as the pivotal point in the plot development of this fable, since the crow drops the coffee when it opens its mouth to retort: "Sama ty vorona!" In this mad context the reader is so taken aback that he can easily forget to ask how a crow manages to hold coffee in its beak and why the home to which it returns is referred to as "paršivyj". The absurdity of the insult exchange between the two animals is especially evident when the fox calls the crow a pig. Because the invective "pig" is applied not to a human but to an animal, it takes on a literal quality: as if the fox were denying the "crowness" of the bird and redefining its species instead of using the word "pig" metaphorically as it is done among humans. As in Charms' previously mentioned fable for children, in this one there is no moral whatsoever, which constitutes a violation of a major convention - if not the goal - characterizing this didactic genre. This is 
of course in keeping with Charms' anti-dogmatic position in virtually all of his work.

The didactic convention in literature is also parodied in a short children's story called 'Rybij žir'. A little boy receives a ten-kopeck coin every time he has a spoonful of horrible-tasting cod-liver oil, and he puts every ten-kopeck coin in his piggy bank. When asked what he does with all his money, he gives an answer which indicates that he will have to suffer forever, in an endless, ridiculous cycle:

- Ну а потом же? спросили Вову.

- А потом, когда у меня в копилке накапливается два рубля, сказал Вова, то мама вынимает их из копилки и покупает мне опять бутылку рыбьего жира.

(Jaccard 1985: 286)

The vicious circle transforms the didactic into the futile, placing the fundamental notion of 'children's text as behavior guide' on its head.

The ludic elements in Charms' oeuvre link his children's literature with his literature for adults, first creating the impression that a familiar genre is about to be used and then destroying it convention by convention in a mad but often very symmetrical and structurally logical game. It appears that plot development in general and the presence of a dynamic plot in particular are the two literary conventions most often subverted by Charms. In this he is naturally not alone in the 20th century. Consider Beckett's Waiting for Godot and many: other examples of absurdist and modernist literature. However, when this plot negation device is applied to children's literature and/or the fairy tale genre, where dynamic action is usually the dominant, a major deviation from an established convention is observed, making a number of Charms' children's stories and texts for adults quite 'different' indeed. It is interesting that genre games in Charms were not only an important feature of his works of fiction, but they also played a prominent role in his personal correspondence. In one letter he plays with the conventions of the traditional salutation and opening questions, thereby undermining the epistolary genre:

\section{1 августа 1932 Курск}

Дорогая Тамара Александровна, Валентина Ефимовна, Леонид Савельевич, Яков Семенович и Валентина Ефимовна.

Передайте от меня привет Леониду Савельевичу, Валентине Ефимовне и Якову Семеновичу.

Как вы живете, Тамара Александровна, Валентина Ефимовна, Леонид Савельевич и Яков Семенович? Что 
поделывает Валентина Ефимовна? Обязательно напишите мне, Тамара Александровна, как себя чувствуют Яков Семенович и Леонид Савельевич.

(Charms 1988: 470)

Here, the deviation from the norm resides in very simple features: the number of addressees and the various combinations of their names in different sentences. The use of the formal patronymics adds an additional ludic element to this list of addressees, contrasting with the clearly playful - and therefore informal - tone of the text.

\section{The Characters: Children and Child-Like Adults}

In many of his works for adults - and naturally in his children's works Charms shows us a universe of the child. At the risk of stating the obvious, we should mention that, as M. McDowell (1976: 141) points out, the presence of child characters is the norm in children's literature and one of the main features distinguishing it from literature for adults. Charms' stories for adults are certainly different from his children's works in this respect since they present adult characters for the most part, but very often these so-called adults are very child-like in their behavior. They are often confused, uncoordinated, strangely misplaced, helpless and immature - like children living in an absurd world devoid of inherent order and direction. These 'adult children' are the grotesque counterparts of real child characters in Charms' children's works.

Aside from child and child-like characters in Charms' two literatures, we also see one other noteworthy character type: in some works for adults there are animal- or vermin-like children, who are perceived very negatively by the narrators and the adult characters. These animalchildren are in great contrast to the child characters of Charms' children's literature. In his works for aduits the child-like adults along with the wretched animal-children are part of a nightmarish vision, which distorts the conventional idea and ideal of the innocent child and the child-like. On the other hand - apart from a few exceptions, which will be dealt with at the end of this paper - the children in Charms' children's literature, instead of trying to make sense of a perplexing world, usually are seen enjoying themselves and playing. Thus, the 'normal' feature of Charms' children's literature has to do with the fact that his child characters partake in happy or silly, typical children's activities: we see children at play, children in the process of creating or discovering and children doing destructive or nasty things that they do when they are naughty. 
Here are two examples of the typically child-like in Charms' children's stories. The model work which epitomizes the idea of child's play is a poem suitably called 'Igra'. It has the archetypal fairy-tale architectonic structure: three young boys pretend to be a car, a mail ship and a Soviet airplane respectively. The poem is full of dynamic action, which, as McDowell (1976: 141) observes, is also typical of children's literature. 'Igra' comes alive with verbal play as each character tells the others what he is doing and imitates the sound of his respective vehicle: "Ga-ra-rar!" "Du-du-du!" and "Žu-žu-žu!". When a cow comes along and blocks their path, thereby interrupting the game for a time, its real animal sound "Mu-mu-mu" creates a playful contrast with the mechanical sound imitations made by the three boys (1988: 232).

Equally typical of children's literature in general is the fabulous voyage motif, which appears in 'Kak Kol'ka Pankin letel v Braziliju i Pet'ka Eršov ničemu ne veril'. A boy imagines a whole glorious adventure in Brazil, as he envisions local, everyday features of Leningrad around him as part of the exotic and exciting setting in his imaginary South American locale. Another boy tries to disrupt this game by not playing along and bringing the flight of his friend's imagination down to earth:

- Ты видел бизона? - спросил Колька.

- Где? - спросил Петька.

- Да ну, там. Он кинулся на нас, - сказал Колька.

- А это не корова была? - спросил Петька.

- Что ты, какая же это корова? В Бразилии нет коров, - сказал Колька.

(1967: n.p.)

These examples are typical of Charms' children's works where he captures the life and behavior of children, adding a touch of fantasy or the absurd. But the absurd elements do not violate the innocent and playful nature of his children's works. There is, however, little doubt that Charms' positive presentation of playful children has to do with the widespread notion that "children's books tend to be optimistic rather than depressive" (McDowell 1976: 141), which is one of the very basic principles of children's literature in general. This requirement was coupled with the fact that Charms had to comply with an ideology that required a generally positive tone in fiction. However, interestingly enough Charms himself in all probability had a very negative view of children, and he certainly did not see them as nearly such delightful creatures as those he portrays in his stories and poems: 
Kharms, who apparently did not like children, had the ability to see the world with the eyes of a child and the artistry of a writer. (Stone-Nakhimovsky 1982: 20)

This comment seems to be supported by Charms' unpublished personal statements: "Ja ne ljublju detej, starikov, staruch i blagorazumnych" (Druskin Fund Archives No. 219, sheet 50). And further on the same page is the macabre remark: "Travit' detej - èto žestoko. No cto-nibud' ved' nado že s nimi delat"'. Another interesting archival document is a little book, consisting of a few sheets of paper sewn together, which contains no words except for those on the front cover: "Evstigneev smeetsja: jumorističeskij rasskaz dlja detej i durakov" (Druskin Fund Archives No. 219 , sheet 43). Furthermore, in the autobiographical work "Ja resil rastrepat' odnu kompaniju" we read the following:

Вот другое дело дети. О них говорят, что они невинны, да только уж больно омерзительны, в особенности когда пляшут. Я всегда ухожу оттудова, где есть дети.

(1988: 450)

This negative view of children finds its clearest expression in the often black humour of Charms' presentation of wretched child-characters in his literature for adults.

An unpublished story called 'Vospitanie' conveys a view of the child and the treatment of children that would be rejected by most children's authors, parents and especially Stalinist censors [the punctuation is Charms']:

Один матрос купил себе дом с крышей. Вот поселился матрос в этом доме и расплодил детей. Столько расплодил детей, что деваться от них стало некуда. Тогда матрос купил няньку и говорит ей: "Вот тебе, нянька, мои дети. Няньчи их и угождай им во всем, но только смотри, чтобы они друг друга не перекусали. Если же они очень шалить будут, ты их полей скипидаром или уксусной эссенцией. Они тогда замолкнут. А потом еще вот что, нянька, ты конечно любишь есть. Так вот уже с этим тебе придется проститься. Я тебе есть давать не буду."

- "Постойте, да как же так? - испугалась нянька. Ведь всякому человеку есть нужно. Ну как знаешь, но только пока ты моих детей няньчишь - есть несмей [sic]!"

Нянька было на дыбы, но матрос стегнул ее палкой и нянька стихла. 


$$
\begin{aligned}
& \text { - Ну а теперь, - сказал марос [sic], - валяй моих со- } \\
& \text { пляков! }
\end{aligned}
$$

И вот таким образом началось воспитание матросских детей.

Выросло у матроса 54 хулигана! Один из них, уже не помню который, прирезал няньку. (1935-1938)

(Druskin Fund Archives No. 264)

This brutal and absurd disciplinary treatment and the vermin-like nature of the children - stressed by their teeming multitude - echoes the abovementioned idea of poisoning children.

In the few other cases when children are mentioned in Charms' literature for adults, they are often being hurt in some fashion or appear as the object of hatred. In 'Sonet' the 'adult' characters argue about which number comes first, 7 or 8 . Then they are distracted by a gruesome incident which they view as entertainment:

Мы спорили бы очень долго, но, по счастыо, тут со скамейки свалился какой-то ребенок и сломал себе обе челюсти. Это отвлекло нас от нашего спора. (1988: 357)

Children are also mutilated - this time in the narrator's mind - in the beginning of the long prose work 'Starucha':

С улицы слышен противный крик мальчишек. Я лежу и выдумываю им казни. Больше всего мне нравится напустить на них столбняк, чтобы они вдруг перестали двигаться. Родители растаскивают их по домам. Они лежат в своих кроватках и не могут даже есть потому что у них не открываются рты. Их питают искусственно. Через неделю столбняк проходит, но дети так слабы, что еще целый месяц должны пролежать в постелях. Потом они начинают постепенно выздоравливать, но я напускаю на них второй столбняк, и они все околевают.

(1988: 399)

Apart from the macabre content, note the incompatibility of the typically child-related diminutive suffix ' $k$ ' in the word "krovatkach" and the term "okolevajut", which is normally used to describe the death of animals.

The desire to get rid of annoying children is also echoed later on in this tale as the narrator-protagonist is bothered by two boys in a train. And yet another time in this text, over vodka with his friend Sakerdon Michajlovič, the narrator-protagonist makes the following comment: “Terpet' ne mogu pokojnikov i detej". To this Sakerdon Michajlovič re- 
marks in a similar vein: "deti, požaluj, chuže, oni čǎ̌̌e mešajut nam" (1988: 414).

The most striking and the most nightmarish reference to children appears in a work called "Ja podnjal pyl", which Charms wrote in February of 1939, four months earlier than 'Starucha'. A man is being pursued in what he perceives to be a chase through a living hell toward a bathhouse [unfortunately only this English translation was available to us]:

I kicked up dust. Children were running after me and tearing their clothing... Torn children rushed after me; and, falling behind, broke their fragile legs in their terrible haste... Filthy, malnourished children looking like poisonous mushrooms got tangled under my feet. I couldn't run... I jumped, ripped the heads off a few mushrooms...

(Stone-Nakhimovsky 1982: 99)

These scattered, poignant and horrific presentations of children in Charms' literature for adults certainly are far removed from the image of playful children which we see in the above-mentioned examples of Charms' children's literature. Perhaps these filthy, animal-like children are not only the products of a world gone mad, but also the progeny of adults who themselves appear helpless and immature in Charms' fantastic universe. These adults are characterized by some of the most negative features associated with children and childhood - traits reminiscent of W. Golding's novel Lord of the Flies. We would like to turn now to these child-like adults and discuss the special place they occupy in Charms' absurd and often frightening world.

To begin with many of Charms' adult character names suggest childish elements, e.g., "Maškin i Koškin", "Fed'ka i Sen'ka", "Pakin i Rakukin" and others. The key element here is the letter 'k' which appears in all six names. When ' $k$ ' is a diminutive suffix - and it acts as such in "Maškin", "Koškin", "Fed'ka" and "Sen"ka" - it is normally associated with the childish, the playful and the informal, i.e., it is a foreign body in the official, serious, everyday world of adults. Although in "Pakin" and "Pakukin" ' $k$ ' is not a suffix, by association it suggests a diminutive concept, not to mention its playful role in "Rakukin", which sounds very much like the work "kukis". 5

While the childishness of these and other adult characters is merely suggested by their names, it is clearly illustrated by their immature behavior. Random, poorly motivated or unprovoked violence, which is often typical of real-life children, is the first - and in our opinion most striking - feature characterizing the behavior of Charms' child-like 
adults. The pages of Charms' works are filled with punches, kicks and slaps which often appear humorous because of their 'Punch and Judy' style. However, there is more to this violence than puppet show aggression; Charms' absurd comic play almost always takes on darker implications as the gratuitous punches result in death or horrible injury. One of the most important factors in Charms' presentation of his fighting adults is the fact that almost in every case neither the characters themselves nor the narrator show any shock or concern about the implications of their actions. Charms' child-like adult characters, like their younger real-life models, are without developed morals and are unable to fully grasp the consequences of violence and death. One is reminded in this respect of the psychiatric definition of psychopathy as a lack of a developed conscience.

Charms presents several pairs of child-like adult fighters. In 'Grjaznaja ličnost' the already mentioned Fed'ka kills Sen'ka in a most absurd way: "[...] Fed'ka dognal Sen'ku i dvinul ego sacharnicej po golove" (1988: 331). The ridiculous murder method, as well as the very colloquial term "dvinul", make the act seem all the more playful and joke-like, obfuscating the moral and emotional implications of killing a human being. To make the situation even more absurd, Fed'ka immediately is narrated out of the scene of the crime as he packs his suitcase and goes off to Vladivostok, where he becomes a tailor of ladies' underwear. Such accumulation of absurd detail turns the adult business of murder into a childish game where nothing is real. It ought to be noted that no reason is given for the violence in this story: it seems to exist for its own sake - as a gratuitous, immature act.

Similarly groundless is the fighting in "Maškin ubil Koškina". Here the two fighters take turns hitting each other, and the simple ending cuts the story off abruptly in a typically absurd and shockingly matter-of-fact way: "Tovarišč Koškin rastjanulsja na polu i umer. Maškin ubil Koškina" (1988: 383). The officially bureaucratic word "tovarišs" creates an additional absurd effect: it is incompatible with the characters' "unofficial" behavior, and this behavior contradicts the harmonious utopian picture of Soviet society suggested by the formal and meaning-laden concept of "comrade'. Furthermore, "tovarišc" followed by a last name is an adult title and is in stark contrast with the child-like behavior of the two characters.

In 'Pakin i Rakukin' the fight story pattern repeats itself: Pakin kills Rakukin after the two anger each other with childish name-calling. In this story the fight goes on beyond the grave: an element of the fantastic is introduced as Rakukin's spirit jumps out of his dead body and sets off in pursuit of his murderer. 
There are two other examples of this story type which we may mention. In 'Čto teper' prodajut v magazinach' a character named Kartygin becomes upset because his friend Tikakeev, who has gone shopping, does not arrive home to meet him on time. In the ensuing squabble Tikakeev takes out a newly purchased cucumber and uses it to kill Kartygin. The absurd last line sums up the absurdity of the whole story: "Vot kakie bol'šie ogurcy prodajut teper' v magazinach!" (1988: 382). The fight in 'Istorija deruščichsja' is formally very similar to that between Maškin and Koškin (cf. above), but this time the two adversaries have dignified and very adult names: Aleksej Alekseevič and Andrej Karlovič. Their fight does not result in a death - although one of them ends up with a torn nostril - but the open ending leaves them still attacking each other. The full names and patronymics of these two characters, which is an attribute of the serious adult world, act as an absurd contrast to their childish behavior just like in the above-mentioned case with 'tovarišč' in 'Maškin ubil Koškina'.

Aside from these examples, in many of Charms' other stories characters are constantly being killed and mutilated; however, groundless or arbitrary childish conflict is not always the cause. Sometimes death or injury occur as a result of ridiculous accidents related to a lack of basic coordination and understanding of the world, which is also reminiscent of a small child's mind. Many characters manifest an infantile inability to avoid danger and end up hurting themselves - sometimes repeatedly unable to learn how to prevent accidents even after having observed or experienced them before. One of the best examples is the helpless protagonist of 'Stoljar Kušakov' who sets off to get glue and never makes it (1988: 361). This story begins like a standard fairy tale - "Žil-byl stoljar"; however, by means of a typical Kharmsian shift, the reader's initial genre expectations are thwarted by an absurd narrative pattern, which, as already mentioned, is found in many other instances: the hero is caught up in a never-ending stream of obstacles, which prevent him from achieving his goal. ${ }^{6}$ Kušakov never gets anywhere as he keeps falling down: he breaks successively his forehead, nose, cheek and chin and has to keep returning to the pharmacy to get bandages. When he finally goes home, he is so bandaged up that his family does not recognize him and throws him out of the house.

Even more child- or even baby-like are the plummeting old women in 'Vyvalivajuščiesja staruchi'. They seem to have regressed to an infantile state, engaging in irrational acts dangerous to themselves. The old women fall out of the window one after another - like children who lack the physical coordination to look out without plummeting to the ground: 
Одна старуха от чрезмерного любопытства вывалилась из окна, упала и разбилась. Из окна высунулась другая старуха и стала смотреть вниз на разбившуюся, но от чрезмерного любопытства тоже вывалилась из окна, упала и разбилась.

(1988:356)

It should be noted that the way in which many of Charms' characters and narrators react to death, mutilation and violence betrays a small child's inability to grasp the seriousness of horrifying events. Whereas most literature - from the Middle Ages through Dante to Goethe - seems to take death very seriously, Charms' child-like characters appear to dismiss it as just another daily activity, denying its finality and its 'grim reaper' image. Everything is no more serious than a child's game of 'let's pretend'. The most extreme example of an immature reaction to serious events is found in a story called 'Reabilitacija'. Here a criminal awaiting his trial rids his behavior of any considerations of guilt or responsibility. His reasoning suggests the conscience of a child whose main goal is to avoid punishment: having committed heinous crimes, but devoid of morals, he does not see that he has done anything wrong:

Не хвастаясь могу сказать, что когда Володя ударил меня по уху и плюнул мне в лоб, я так его схватил, что он этого не забудет. Уже потом я бил его примусом, а утюгом я бил его вечером. Так что умер он совсем не сразу. Это не доказательство, что ногу я отрезал ему еще днем. Тогда он был еще жив. А Андргошу я убил просто по инерции, и в этом я себя не могу обвинить. Зачем Андргоша с Елизаветой Антоновной попались мне под руку? Им было не к чему выскакивать из за двери. Меня обвинягот в кровожадности, говорят, я пил кровь, но это неверно, я подлизывал кровяные лужи и пятна; это естественная потребность человека уничтожить следы своего, хотя бы пустяшного преступления. А также я не насиловал Елизавету Антоновну. Во-первых, она уже не была девушкой, а во-вторых, я имел дело с трупом, и ей жаловаться не приходится. Что из того, что она вот-вот должна была родить? Я и вытащил ребенка.

(Rossija 7, 1991:8)

We would like to contrast this striking example of naive sophistry in reaction to death and violence with the only 'normal' or 'mature' reaction to terrible events in all of Charms' stories known to us: 'Sud'ba ženy professora'. A professor dies in a Moscow hospital a few days after having eaten something bad. His ashes are mailed in a package back to his 
wife. She reads the words: "Vot vse, čto ostalos' ot Vašego supruga" and is apparently affected by the news:

\begin{abstract}
Жена ничего понять не может, трясет баночку, на свет ее смотрит, записку шесть раз прочитала - наконец, сообразила, в чем дело, и страшно расстроилась. Жена профессора очень расстроилась, поплакала часа три и пошла баночку с пеплом, хоронить.
\end{abstract}

(Raduga 7, 1988: 33)

However, here again, despite its seeming normality, the mourning is made absurd by the pragmatic specification of its duration: "časa tri", and its very temporary quality is stressed by the prefix "po-" in the verb "poplakala", which usually conveys short duration and in this case trivializes the woman's grief. The word "rasstroilas", which is clearly too weak to convey real sorrow, further weakens the reaction of the professor's wife. It is as if the narrator does not allow his character to react in an 'adult' way to an event whose gravity normally elicits a much more mature response. The grieving woman is restricted even further in her attempt at a 'normal' reaction to death when some people from the insane asylum arrive and take the "soveršenno normal'naja professorša" - as the narrator puts it, to a madhouse. Thus, the only mature character in Charms' stories is suppressed and deprived of the chance to behave in a non-childish way.

The immature and even clownish child-like adult also appears in Charms' stories about famous men. Great artists and authors are presented as ridiculous clowns, acting in a manner that sharply contrasts with their serious reputation. The best known example of this grotesque metamorphosis is the story 'Puškin i Gogol', where two of Russia's greatest authors keep stumbling over each other on stage, falling down and cursing:

Гоголь падает из-за кулис на сцену и смирно лежит.

Пушкин (выходит, спотыкается об Гоголя и падает): Вот черт! Никак об Гоголя!

Гоголь (поднимаясь): Мерзопакость какая! Отдохнуть не дадут (Идет, спотыкается об Пушкина и падает.) Никак об Пушкина спотыкнулся!

Пушкин (поднимаясь): Ни минуты покоя! (Идет, спотыкается об Гоголя и падает.) Вот черт! Никак опять об Гоголя!

$(1988: 360)$ 
Once again we have a story that never gets started and consists of the same repeated sequence. The two 'authors' use very colloquial expressions and curse in a way that is completely incompatible with the reader's expectations: two giants of Russian literature behave like drunken goons. The falling literati resemble babies who have barely learned to walk, and apart from their names, they retain nothing of their famous identities. ${ }^{7}$

Basic bodily functions are associated with Lev Tolstoj in a dream seen by the wife of the deceased professor in the above-mentioned story 'Sud'ba ženy professora'. Tolstoj resembles a proud two-year-old who has produced something quite impressive:

\begin{abstract}
Идет она и спит. И видит сон, будто идет к ней навстречу Лев Толстой и в руках ночной горшок держит. Она его спрашивает: "Что же это такое?" А он показывает ей пальцем на горшок и говорит:

- Вот, - говорит, - тут я кое-что наделал, и теперь несу всему свету показывать. Пусть, - говорит, - все смотрят. (Raduga 7, 1988:33-34)
\end{abstract}

In this case the act of creation is brought down to the physiological level of a child's capabilities: instead of the expected literary work, the great author has produced the least intellectual thing possible.

General ignorance and naïveté turn a number of Charms' adult characters into children who are unable to perform the most basic everyday tasks. Kindergarten-level counting is the subject of a story called 'Sonet'. A man suddenly forgets which comes first: seven or eight. He goes to his neighbors for help, but they cannot figure it out either, and they all approach a cashier in a store who confuses them even more with the absurd statement:

По-моему, семь идет после восьми в том случае, когда
восемь идет после семи. (1988: 357)

Confused even further, these helpless adults argue and then eventually just go home. In this case not one but all the adult characters lack a basic skill normally possessed by schoolchildren. This is pushed to the limit of absurdity when the cashier, who should be able to count better than anyone else, having to work with numbers constantly, is unable to offer any assistance to the helpless counters. Not only does she fail to help them, but she confuses them even more with a circular argument, which destroys the concept of basic sequential progression. ${ }^{8}$ 
As a final example of the childish in Charms' adult characters we would like to take 'Načalo očen' chorošego letnego dnja' - a text which contains almost all of the elements and manifestations of immature behavior discussed above. The result is a phantasmagoric kindergarten for adults and a chaotic scene where only the characters' bodies are mature:

\begin{abstract}
Чуть только прокричал петух, Тимофей выскочил из окошка на крышу и напугал всех, кто проходил в это время по улице. Крестьянин Харитон остановился, поднял камень и пустил им в Тимофея. Тимофей куда-то исчез. "Вот ловкач!" - закричало человеческое стадо, и некто Зубов разбежался и со всего маху двинулся головой об стену. "Эх!" - вскрикнула баба с флюсом. Но Комаров сделал этой бабе тепель-тапель, и баба с воем убежала в подворотню. Мимо шел Фетелюшин и посмеивался. К нему подошел Комаров и сказал: Эй ты, сало! - и ударил Фетелюшина по животу. Фетелюшин прислонился к стене и начал икать. Ромашкин плевался сверху из окна, стараясь попасть в Фетелюшина...
\end{abstract} (1988: 394)

It is as if Charms had put all his child-like adults in one story and in one place, allowing them to run loose and do all the things that they have done in his other texts. This 'kindergarten' is not the innocent place which the term usually suggests by its flower image. This is rather an upside down kindergarten where innocence is transformed into idiocy and play into violence.

Thus, the world created in Charms' stories for adults is a dangerous, violent and often nightmarish domain. This is frequently the result of immature behavior on the part of its adult inhabitants who are very similar to children in their mentality, but, unlike children, they are not controlled by a higher authority and remain free to wreak havoc. In his children's literature, as we have seen, Charms creates a largely pleasant playful universe, while many of Charms' adult characters from his stories for adults act as a kind of concealed warped and frightening counterpart to the children from his children's works. The fact that Charms' 'normal' child was intended for the public while his grotesque childish adult was not brings to mind Freud's 'id' and 'ego' relationship. Thus, in this dichotomy of child and child-like character types we see Charms' private and public face, the former having been kept in total secret during the author's short life:

Хармс сам очень любил рисовать, [writes one of his friends] но мне свои рисунки никогда не показывал, а также все, 
что он писал для взрослых. Он запретил это всем своим друзьям, а с меня взял клятву, что я не буду пытаться достать его рукописи.

(Poret 1980: 357)

\title{
The Darker Side of the Child's World
}

As mentioned previously, Daniil Charms' children's literature seems to portray a playful, pleasant, positive world as opposed to his literature for adults:

\begin{abstract}
Активная творческая жизнь ребенка - нового героя Хармса - стала для него своего рода антитезой ужасу прозябания, изображенному в его 'взрослых' вещах.
\end{abstract}

(Petrovskij 1968: 259)

However, we would like to mention two children's works that deviate from the general tendency in Charms' happy world of the child. A knowledge of Charms' secret literature for adults and of his position in the Soviet literary institution may explain why in the following two stories this author was incapable of preventing aspects of his adult nightmare from creeping into his children's literature.

The horrible, absurd violence of Charms' adult universe intrudes in a rather overt way into the child's world in the story 'Skazka'. As already mentioned above, a little boy, Vanja, wants to write a typical fairy tale, but a little girl, Lenočka, says that all the stories proposed by Vanja have already been written and then proceeds to tell her own versions of them. On the formal level this is an excellent example of a game involving metafictional self-referentiality: the story ends with Vanja buying a copy of the magazine which contains the story about him that we have just read. Furthermore, 'Skazka' has another ludic feature that we have discussed above: the distortion of the conventional fairy-tale form. However, beneath the humorous impact of these formal games lie frightful images of absurd violence which are far from the realm of a child's world. When the little boy expresses the desire to write a story about a king and a queen, the little girl tells him that such a story has already been written and proves her point with the following macabre narrative:

- [...] Король пил чай с яблоками и вдруг подавился, а
королева стала бить его по спине, чтобы кусок яблока
выскочил из горла обратно. А король подумал, что коро-
лева дерется, и ударил ее стаканом по голове. Тут коро-
лева рассердилась и ударила короля тарелкой. А король
ударил королеву миской. А королева ударила короля 
стулом. А король вскочил и ударил королеву столом. А королева повалила на короля буфет. Но король вылез из под буфета и пустил в королеву короной. Тогда королева схватила короля за волосы и выбросила его в окошко. Но король влез обратно в комнату через другое окно, схватил королеву и запихал ее в печку. Но королева вылезла через трубу на крышу, потом спустилась по громоотводу в сац и через окно вернулась обратно в комнату. А король в это время растапливал печку, чтобы сжечь королеву. Королева подкралась сзади и толкнула короля. Король полетел в печку и там сгорел. Вот и вся сказка, сказала Леночка.

(1967: n.p.)

This story certainly reminds us of the numerous texts about puppet-like fighting men in Charms' world of child-like adults. However, the horror of 'Skazka' is even more striking since its form is taken from a traditional children's genre. Using the traditional fairy tale beginning "Žil-byl korol'...", which, as E. Rabkin (1976: 34) points out, is a clearly conventional welcome sign into the attractive - in spite of occasional danger - world of enchantment, Lenočka suddenly tells horrible, absurd things as if they were not in contrast with the conventional world of the children's fairy tale. The little boy's reaction to the story shows that he does not see its nightmarish quality as anything out of the ordinary, bringing to mind the immature way in which many of Charms' adult characters and narrators react to death and injury in his works for adults: "Očen' glupaja skazka. Ja chotel napisat' sovsem druguju" (1988: 276). "Glupaja" is hardly appropriate as a qualifier for such a deviation from our genre expectations. The specific act of stuffing someone into the oven is reminiscent of scenes from "Hansel and Gretel" or the Russian Baba-Jaga. However, unlike these stories, in which punishment of the evil witch is motivated, here the whole shocking episode is based on a simple misunderstanding. This is much more a world of existentialist rather than enchanted reality.

Pain and mutilation, normally kept at a distance in conventional children's literature, are not only present in a story called 'Moločnyj zub'; but they appear as an absurd, unnecessary phenomenon, very much like their counterparts in Charms' literature for adults. A little girl is very frightened because she has to have a tooth pulled. She is in the editorial offices of a publishing house - terrified. When she explains her problem to a female editor, the latter tells her that getting a tooth pulled is no more painful than being pricked with a pin. Thus far we have a very typical didactic children's plot, but at this point the absurd takes over. Rather than using the pinprick comparison just figuratively, as we would expect, 
the editor demonstrates it by really pricking the little girl with a real pin and then explaining: "rvat' moločnyj zub ne bol'nee ètogo ukola" (Druskin Fund Archives No. 281). Thus, we observe the rather absurd and sadistic act of causing pain to a child in order to show that future pain would be bearable. This 'literalization' of a figurative comparison pain=pinprick - does introduce a ludic element to be sure, but it also strips the child's world of some of its innocence. Danger and pain become not abstract notions but real experience; what is more, the pain is caused by a well-meaning adult. And since pain in this case is unnecessary and futile, it is all the more frightening to a young mind. The narrator, like many narrators of Charms' works for adults that describe absurd and random injury, does not find anything strange about this whole incident and actually praises the pin-wielding editor: "Možno tol'ko otmetit' nachodčivost' ètoj redaktorši."

\section{Conclusion}

Charms' literature is characterized by three major trends, each one consisting of contrasting elements:

a) his relatively bright children's works versus his very macabre texts for adults;

b) endless random and often bloody violence versus its 'Punch and Judy' features which make it difficult to take seriously;

c) the formal games and funny twists of plot and language versus the more tragic or downright frightful aspects of Charms' absurd universe.

It becomes clear that the young, the in-between and the old are all caught up in a vortex of horror and laughter which confuses a reader who is used to - and therefore expects - more conventional patterns. Because of genre requirements and ideological pressure from the Soviet literary institution, Charms' children's works had to be more pleasant and less ambiguous than his literature for adults. Nevertheless, it is to be hoped that our discussion of his children's works against the background of his secretly written works for adults has demonstrated that Charms' two literatures are definitely the product of the same pen. Charms was very much aware of what the reader's conventional expectations were, and whenever he could get away with it publicly and almost always in his private writings - he would systematically violate these expectations, creating an upside down effect typical of absurdist writing in general. It is now hopefully clear that Charms, the writer for adults, and Charms, the children's author, influenced each other, producing works that fit neither the conventional expectations of adult readers nor oftentimes those of children. This is of course very fitting for a century that has been charac- 
terized by the destruction of conventions and for a writer who lived and worked in a society full of terror and the unexpected.

University of Alberta

NOTES

1 These were 'Slucaj na železnoj doroge' in the collection of the Leningrad Union of Poets published in 1926 and 'Stich Petra Jakšina' in another collection published by the same source in 1927.

2 Ironically, this purposeful 'antonymy' of the literature of the absurd sometimes makes it rather predictable in spite of its quest for originality, for a world upside down tends to follow the patterns of our world - only backwards.

Мы - первые враги тех, кто холостит слово и превращает его в бессильного и бессмысленного ублюдка.

(Milner-Gulland 1970: 70)

4 The use of meaningless phonemes is also found in two dog names, which appear in an unfinished text without a title: "Gynmynfynbyn" and "Bububu" (Druskin Fund Archives No. 219, sheet 17).

5 Because "kukiš" is the word for a gesture, which indicates a refusal to cooperate or share and is especially common among Russian children, it serves to render Rakukin's name that much less formal and immature. Just like the diminutive ' $k$ ', it is foreign to the serious world of adults.

6 This is related to another narrative pattern discussed above: a story that ends without ever getting off the ground.

7 Puškin also appears as uncoordinated as a child in the cycle entitled 'Anekdoty iz žizni Puškina' where the whole story consists of the fact that Puškin and his son are unable to sit at a table and keep falling from their chairs (1988: 393).

8 This story about number confusion is strikingly similar to a more recent text by a modern children's writer, Oleg Grigor'ev. Just like Charms, he is from Leningrad and, until the Gorbačev era, his works suffered a fate similar to that of his absurdist predecessor. Grigor'ev's story is entitled 'Lestnica':

Поднимаясь по лестнице домой, Петров насчитал восемь ступенек; спускаясь по лестнице вниз, насчитал только семь. 
As the narrative progresses, the seven-eight discrepancy in the staircase [note that in Charms' story the numbers are also seven and eight], is discovered by different characters: a building custodian, a policeman and even the civil engineer responsible for the construction of the building. Just like Charms' perplexed characters, Grigor'ev's characters come up with an absurd solution: the staircase is torn down, and the reader learns the following:

Теперь, когда Петров идет домой, он подпрыгивает на восемь ступенек вверх, а когда выходит из дома, прыгает на семь ступенек вниз.

(Grigor'ev 1990: 30)

\section{BIBLIOGRAPHY}

Abrams, M.H.

1981 A Glossary of Literary Terms. New York.

Aleksandrov, A.

1968

1978

1984

1988

Begak, Boris

1936

Chalatov, N.

1966

'Daniil Charms - kto že on nakonec?'. Detskaja literatura, 1, 23-25.

Chances, Ellen

1985

'Daniil Charms' "Old Woman" Climbs her Family Tree: "Starucha" and the Russian Literary Past'. Russian Literature, XVII-IV, 353-366.

Charms, Daniil

1967

Čto èto bylo? Moskva.

1974

Izbrannoe (Ed. George Gibian). Würzburg.

1987

'...i emu v Rot zaletela kukuska (iz prozy i poèzii Daniila Charmsa)'. Voprosy literatury, 8, 262-275. 
1988 Polet $v$ nebesa (red. A. Aleksandrov). Leningrad.

1988 'Works'. Raduga, 7, 31-38.

1989 'Stichotvorenija'. Detskaja literatura, 4, 72-79.

1989 The Plummeting Old Women (Trans. N. Cornwell). Dublin.

1990 Letjat po nebu šariki (red. A. Aleksandrov i N. Kavin). Krasnojarsk.

1991 'Golye ljudi derutsja nogami'. Rossija, 7 (15), fevr. 16-22, 8. Dovlatov, S.

1968

Druskin Fund

'Nezrimye boi'. Neva, 9, 197-198.

Archive Department of the Saltykov-Ščedrin Library. SanktPeterburg.

Esslin, Martin

1980 The Theatre of the Absurd. Harmondsworth.

1982 'Ionesco and the Fairytale Tradition'. The Dream and the Play: Ionesco's Theatrical Quest (Ed. Moshe Lazar). Malibu.

Etkind, Efim

1978 Notes of a Non-Conspirator. Oxford-London-New York.

Even-Zohar, Itamar

1979 'Polysystem Theory'. Poetics Today, December.

Gerasimova, A.

1988 'On tak i ostalsja rebenkom'. Detskaja literatura, 4, 32-35.

1988 'Problema smešnogo v tvorčestve obèriutov' (dissertacija). Moskva.

Gibian, George

1987 'Introduction'. The Man in the Black Coat: Russia's Literature of the Absurd. Evanston.

Glocer, V.

1989 'Charms sobiraet knigu'. Russkaja literatura, 1, 206-212.

1990 'Dnevnik Daniila Charmsa'. Knižnoe obožrenie, 19, janvar', 89.

Grigor'ev, O.

1990 'Lestnica'. Ogonek, avgust, 30.

Ionesco, E.

1954 Three Plays (Eds. H.F. Brookes and C.E. Fraenkel). London. Jaccard, Jean-Philippe

1985 'De la réalité au texte: l'absurde chez Daniil Harms'. Cahiers du Monde Russe et Soviétique, XXVI (3-4) juil-déc., 269-312.

Jost, François

1974 Introduction to Comparative Literature. Indianapolis.

Killinger, John

World in Collapse: The Vision of Absurd Drama. New York. 
Loseff, Lev

1984 On the Beneficence of Censorship: Aesopian Language in Modern Russian Literature. München.

Margolina, S.

1930 'Konfety i ežiki'. Kniga i revoljucija, 28, 19-22.

Marsak, Samuil

1972 Sobranie sočinenij, t. 8. Moskva.

McDowell, Myles

1976 'Fiction for Children and Adults: Some Essential Differences'.

Writers, Critics and Children (Eds. Geoff Fox et al.). London, 140-156.

Milner-Gulland, R.R.

1970 'Left Art in Leningrad: The Oberiu Declaration'. Oxford Slavonic Papers, New Series III, 65-75.

Müller, Bertram

1978 Absurde Literatur in Rußland. München.

O'Dell, F.A.

1978 Socialisation through Children's Literature. Cambridge.

Petrovskij, Miron

1968 'Vozvraščenie Daniila Charmsa'. Novyj mir, 8, 258-260.

Poret, A.

1980 'Vospominanija o Daniile Charmse'. Panorama iskusstv, 3. Moskva, 345-359.

Rabkin, E.

1976 The Fantastic in Literature. Princeton.

Rachtanov, I.

1971

Šatilov, B.

1929 'Ež'. Oktjabr', 12, 184-189.

Sažin, V.N.

1985

Rasskazy po pamjati. Moskva.

'Literaturnye i fol'klornye tradicii v tvorčestve D.I. Charmsa'. Literaturnyj process i razvitie russkoj kul'tury, XVII-XX vv. Tallin, 57-61.

Semenov, B.

1977

‘Čdak istinnyj i radostnyj’. Avrora, 1, 69-75.

Shavit, Zohar

1986

Slonim, Marc

1977

Poetics of Children's Literature. Athens, Georgia.

Soviet Russian Literature: Writers and Problems 1917-1977.

New York.

Sluckij, B.

'O Charmse'. Junost', 9. 
Smeljanskij, A.

1990

'Obèriu, ili neskol'ko večerov v sumaš̌edšem dome'. Moskovskie novosti, 20 maja, 11.

Sokol, E.

1984 Russian Poetry for Children. Knoxville.

Stone-Nakhimovsky, Alice

1982 Laughter in the Void: An Introduction to the Writings of Daniil Kharms and Alexander Vvedenskii. Wiener Slawistischer Almanach, Sonderband 5.

Trenin, V.

1939 'O smešnoj poèzii'. Detskaja literatura, 9, 20-25.

Žavoronkova, A.

1935 'Kritika i bibliografija: žurnaly dlja mladšego vozrasta'. Detskaja literatura, janvar', 22-30. 